\title{
Effect of Lasalocid on Growth, Blood Gases, and Nutrient Utilization in Dairy Goats Fed a High Forage, Low Protein Diet
}

\author{
C.-M. J. Yang, ${ }^{*}$ C-T. Chang, ${ }^{*}$ S.-C. Huang, ${ }^{\star}$ and T. Changt \\ *Department of Animal Science \\ National I-Lan University, \\ I-Lan, Taiwan 260 ROC \\ †Department of Animal Science \\ National Ping-Tung University of Science and Technology \\ Ping-Tung, Taiwan 912 ROC
}

\section{ABSTRACT}

This study investigated the effect of lasalocid on weight gain, blood gases, nutrient digestibility, and nitrogen utilization in growing dairy goats. In a growth experiment, 24 crossbred dairy does were assigned to diets without or with lasalocid (approximately $30 \mathrm{mg}$ per head per day) for 12 wk. Goats were group fed bermudagrass hay for free choice plus concentrate at a fixed level (approximately $0.264 \mathrm{~kg} \mathrm{DM}$ per head per d). Goats grew faster when fed lasalocid than those fed the control diet. Jugular blood partial pressure of $\mathrm{O}_{2}$ was lower when goats were supplemented with lasalocid. In contrast, goats fed lasalocid tended to have a higher partial pressure of $\mathrm{CO}_{2}$ than control goats. Percent $\mathrm{O}_{2}$ saturation tended to increase, and concentrations of total $\mathrm{CO}_{2}$ tended to decrease in goats fed lasalocid. Serum glucose and urea $\mathrm{N}$ did not differ between treatments. In a metabolism experiment, 8 castrated male goats were fed hay and concentrate identical to those of the growth experiment to determine whole tract nutrient digestibility and $\mathrm{N}$ utilization. Lasalocid did not affect feed intake or nutrient digestion coefficients. Daily urinary N output was reduced by lasalocid supplementation. In spite of this, $\mathrm{N}$ retention was not significantly affected. With use of ionophore, the proportion of urinary $\mathrm{N}$ relative to digested $\mathrm{N}$ tended to decrease, and the retained $\mathrm{N}$ as a proportion of digested $\mathrm{N}$ tended to increase.

(Key words: dairy goat, growth, lasalocid, nitrogen utilization)

Abbreviation key: $\mathbf{A D L}=$ acid detergent lignin, $\mathbf{p} \mathbf{O}_{2}$ $=$ partial pressure of $\mathrm{O}_{2}, \mathbf{p} \mathbf{C O}_{2}=$ partial pressure of $\mathrm{CO}_{2}$.

\section{INTRODUCTION}

Lasalocid, an ionophore similar to monensin, has been used to improve weight gain and feed efficiency

Received October 1, 2002.

Accepted July 15, 2003.

Corresponding author: C.-M. J. Yang; e-mail: cmyang@niu.edu.tw. of ruminants (Bergen and Bates, 1984; Van Nevel and Demeyer, 1988). Part of the ionophore effect is a result of decreased methane and increased propionate in ruminal fermentation (Bergen and Bates, 1984; Russell and Strobel, 1989). Propionate is converted to glucose after absorption, and thus is an important glucogenic precursor for ruminants (Wiltrout and Satter, 1972). Glucogenic amino acids are also precursors for glucose. Therefore, increasing propionate could potentially spare glucogenic amino acids.

Ionophores may also inhibit ruminal amino acid deamination (Russell and Martin, 1984; Beacom et al., 1988; Yang and Russell, 1993). This effect could increase amino acids for absorption. It also could minimize energy cost for converting excess ammonia absorbed into urea. It therefore appears that inhibition of methane formation and deamination in the rumen by ionophores both could result in conservation of energy and amino acids.

Diets containing large amounts of forage generally lead to a high-acetate, low-propionate type of ruminal fermentation (Van Soest, 1982). In addition, when animals are fed high amounts of low quality forage and concentrate with a high rumen degradable protein content, there is often an imbalance between ruminal protein (high CP degradability) and carbohydrate fermentation (low carbohydrate availability), and excess ammonia can accumulate in the rumen (Nocek and Russell, 1988).

Based on actions by ionophores to increase propionate and reduce ammonia in the rumen, ruminant animals would be conducive to respond from ionophore supplementation when diets contain large amounts of low quality forage plus small amounts of $\mathrm{CP}$ as true protein with high solubility (Beede et al., 1986). Ionophores can also modulate the translocation of ions across cellular membranes post absorption (Bergen and Bates, 1984). This action may alter tissue acid/base status and metabolic activity, reflecting changes in blood gases.

Replacement dairy ruminants are generally fed high amounts of forage with limited supplementation of con- 
centrate. These diets may limit the performance of animals with high demands for energy and amino acids. Goats are seasonal breeders. Manipulation of weight gain could be used to adjust the age of dairy does at breeding and subsequent age at kidding. This management strategy also offers an opportunity to regulate the time of the year when does start peak milk production in concert with seasonal market demand for raw milk. The objective of this study was to investigate the effect of lasalocid supplementation on growth rate, blood metabolites, and nutrient digestibility and utilization in growing dairy goats fed diets based on poor quality forage and concentrate at a controlled intake.

\section{MATERIALS AND METHODS}

\section{Growth Study}

Twenty-four crossbred (Alpine $\times$ Nubian $\times$ Sannan) growing female dairy goats $(27.4 \mathrm{~kg}, \mathrm{SE}=1.3 \mathrm{~kg})$ were housed in a commercial goat barn covered by openside sheds with an elevated metal floor. The does were randomly assigned to four pens, which were assigned again at random to one of the two dietary treatments, without (control) or with lasalocid (approximately 30 mg per head per d) supplementation. Each pen contained 6 goats, and there were two pens per treatment.

The study lasted for $12 \mathrm{wk}$. All does were group fed chopped bermudagrass hay ad libitum (approximately $2.2 \% \mathrm{BW}, \mathrm{DM}$ basis) and a commercial concentrate at a regulated level (approximately $0.268 \mathrm{~kg} \mathrm{DM}$ per head per d). The feeding regime was estimated to marginally exceed maintenance requirement for $\mathrm{ME}$ and $\mathrm{CP}$ (NRC, 1981). The commercial concentrate mix consisted of $53.0 \%$ ground corn, $17.7 \%$ soybean meal, $11.5 \%$ wheat bran, $16.2 \%$ alfalfa meal, $0.40 \%$ limestone, $0.40 \%$ dicalcium phosphate, $0.40 \%$ salt, $0.20 \%$ trace mineral salt, and $0.20 \%$ vitamin premix, on a fresh basis. Lasalocid was added as a commercial premix via mixing with the concentrate to achieve the desired dietary amount. Both feeds were provided to goats twice daily, and water and mineral salt block were available for ad libitum access. Chemical composition of hay and concentrate fed is shown in Table 1.

Goats were weighed at the start of the study and every other week thereafter to determine live weight gain. Hay and concentrate were fed separately, and concentrate was always consumed completely within $15 \mathrm{~min}$ after each feeding. Orts, only hay, were removed before each feeding. Hay and concentrate were sampled weekly. After determination of $\mathrm{DM}\left(55^{\circ} \mathrm{C}, 48 \mathrm{~h}\right)$, individual feed samples were ground ( $1 \mathrm{~mm}$ ) for later analysis. Ash, DM, ether extract, and CP by Kjeldahl were determined according to methods in AOAC (1984). For soluble $\mathrm{CP}$, feeds were immersed in distilled water at $39^{\circ} \mathrm{C}$
Table 1. Chemical composition of bermudagrass hay and concentrate fed to growing dairy goats.

\begin{tabular}{lcc}
\hline Items $^{1}$ & Hay & Concentrate $^{2}$ \\
\hline Dry matter (DM), \% & 91.2 & 89.4 \\
Ash, \% DM & 6.38 & 6.51 \\
Organic matter, \% DM & 93.6 & 93.5 \\
CP, \% DM & 6.92 & 12.8 \\
Soluble protein, \% CP & 75.0 & 77.2 \\
Ether extract, \% DM & 1.52 & 3.38 \\
NDF, \% DM & 74.3 & 30.8 \\
ADF, \% DM & 36.0 & 12.4 \\
Cellulose, \% DM & 27.6 & 10.2 \\
ADL, \% DM & 7.26 & 2.70 \\
NFC, \% DM & 10.8 & 46.7 \\
Cell contents, \% DM & 25.7 & 69.2 \\
Hemicellulose, \% DM & 38.2 & 18.5 \\
\hline
\end{tabular}

${ }^{1} \mathrm{ADL}=$ acid detergent lignin $; \mathrm{NFC}=$ nonfiber carbohydrate (organic mater - CP - ether extract - NDF).

${ }^{2}$ Contained $53.0 \%$ ground corn, $17.7 \%$ soybean meal, $11.5 \%$ wheat bran, $16.2 \%$ alfalfa meal, $0.40 \%$ limestone, $0.40 \%$ dicalcium phosphate, $0.40 \%$ salt, $0.20 \%$ trace mineral salt, and $0.20 \%$ vitamin premix, on a fresh basis.

for $1 \mathrm{~h}$ before filtration through Whatman 54 filter paper (Whatman, Clifton, NJ). The residues on the paper were analyzed for CP and designated as insoluble CP. Soluble CP was estimated as difference between total $\mathrm{CP}$ and insoluble CP. Determinations of NDF, ADF, and acid detergent lignin (ADL) were made as described by Van Soest et al. (1991). Cell contents (DM - NDF), hemicellulose (NDF - ADF), and cellulose (ADF - ADL) were calculated by differences.

Jugular blood samples were collected using heparinized syringes approximately $2 \mathrm{~h}$ after the a.m. feeding on wk 12 of the trial. The syringes were chilled in an ice bath immediately and transported to the laboratory within $1 \mathrm{~h}$. Blood partial pressure of gaseous $\mathrm{O}_{2}$ dissolved in blood ( $\left.\mathbf{p} \mathbf{O}_{2}\right)$, partial pressure of $\mathrm{CO}_{2}\left(\mathbf{p} \mathbf{C O}_{2}\right)$, total $\mathrm{CO}_{2}$, and percent $\mathrm{O}_{2}$ saturation were measured by a semiautomatic system (Ciba-Corning 278 Blood Gas System, Medfield, MA) adjusted for hematocrit. Aliquots of blood taken were extracted for serum by centrifugation $(1500 \times \mathrm{g})$ for $20 \mathrm{~min}$ at $4^{\circ} \mathrm{C}$, and were stored at $-20^{\circ} \mathrm{C}$ until further analysis. Serum samples were measured for glucose and urea $\mathrm{N}$ by an automatic instrument (Vitalab Selectra, Merck, Germany).

\section{Whole Tract Digestion and Nitrogen Balance Experiment}

Eight castrated crossbred growing dairy goats (25.5, $\mathrm{SE}=1.1 \mathrm{~kg}$ ) were assigned randomly to one of two dietary treatments identical to those of growth study. The trial was a single crossover design with two periods. The castrates were housed in individual stainless steel crates, designed for quantitative separation of urine and feces. The experiment was conducted during the 
time of the growth study. For each experimental period, total collections of feces and urine were made over $7 \mathrm{~d}$ after a $14 \mathrm{~d}$ adaptation to experimental diets. Goats were fed twice daily at 0800 and 1800 , and water and mineral salt block were supplied ad libitum. Concentrate $(0.268 \mathrm{~kg}$ DM per head per d) was also eaten completely within 15 min after each feeding. Hay, concentrate, and orts samples, and total feces and urine were collected daily and pooled over the 7-d period. Daily feces collected were refrigerated $\left(4^{\circ} \mathrm{C}\right)$ for later analysis. At the termination of each collection period, fecal samples were dried at $75^{\circ} \mathrm{C}$ in a forced-air oven and weighed. Feed and orts samples collected were prepared as fecal samples. Urine was collected into glass jars that were emptied daily. Fifty milliliters of $50 \%$ $\mathrm{HCl}$ were placed in each urine collection jar at the beginning of each daily collection to prevent loss of ammonia. Daily urine volumes were measured, and a $10 \%$ aliquot taken, composited with previous aliquots for each goat. Urine samples were frozen $\left(-20^{\circ} \mathrm{C}\right)$ at the end of each collection period. Sample preparation and analysis of feed, orts, and feces were made by methods identical to those described in growth study. Urine was analyzed for $\mathrm{N}$ using the Kjeldahl technique (AOAC, 1984). Nutrient digestibility and $\mathrm{N}$ retention were calculated by difference between intake and fecal output, and difference between digested $\mathrm{N}$ and urinary $\mathrm{N}$ output. Treatments assigned to each goat were reversed during the second experimental period. To minimize treatment carryover effect, all castrates were fed the control diet for $10 \mathrm{~d}$ between the two experimental periods.

\section{Statistical Analysis}

Data from the growth study were analyzed as a completely randomized design by ANOVA using the GLM procedure of SAS (1996), with goats as experimental units. Treatment was the only effect in the model. For metabolism experiment, the data were analyzed as a crossover design with two periods also by the GLM procedure of SAS (1996). The main effects were treatment, animal, and period. All data were expressed as least squares means. Significance was declared at $P<$ 0.05 unless otherwise indicated.

\section{RESULTS AND DISCUSSION}

\section{Growth Study}

Effect of supplemental lasalocid on BW, weight gain, and blood measurements is presented in Table 2. Initial and final BW did not differ significantly between treatments. Changes in BW during the experiment were small for all does and were 13.6 and $18.5 \%$ for diets
Table 2. Body weight, average daily gain, jugular blood $\mathrm{pO}_{2}$ (partial pressure of $\mathrm{O}_{2}$ ), $\mathrm{pCO}_{2}$ (partial pressure of $\mathrm{CO}_{2}$ ), percent $\mathrm{O}_{2}$ saturation, and total $\mathrm{CO}_{2}$, and selected serum metabolites in growing dairy does fed a high forage-low protein diet without (Control) or with lasalocid (approximately $30 \mathrm{mg} / \mathrm{head} / \mathrm{d}$ ) supplementation.

\begin{tabular}{lclll}
\hline Item & Control & Lasalocid & SEM & $P$ \\
\hline BW, kg & & & & \\
$\quad$ Initial & 27.3 & 27.5 & 1.3 & 0.82 \\
$\quad$ Final & 31.0 & 32.6 & 1.4 & 0.41 \\
Weight gain, kg/d & $0.044^{\mathrm{b}}$ & $0.062^{\mathrm{a}}$ & 0.006 & 0.04 \\
Blood & & & & \\
$\mathrm{pO}_{2}, \mathrm{~mm} \mathrm{Hg}$ & $48.6^{\mathrm{a}}$ & $44.4^{\mathrm{b}}$ & 1.3 & 0.04 \\
$\mathrm{pCO}_{2}, \mathrm{~mm} \mathrm{Hg}$ & $30.1^{\mathrm{d}}$ & $32.8^{\mathrm{c}}$ & 0.9 & 0.09 \\
$\mathrm{O}_{2}$ saturation, \% & $56.3^{\mathrm{d}}$ & $63.0^{\mathrm{c}}$ & 2.6 & 0.08 \\
$\quad$ Total $\mathrm{CO}_{2}, \mathrm{mmol} / \mathrm{L}$ & $30.7^{\mathrm{c}}$ & $29.3^{\mathrm{d}}$ & 0.4 & 0.09 \\
Serum, mg/dl & & & & \\
$\quad$ Glucose & 73.9 & 74.2 & 3.4 & 0.86 \\
Urea N & 15.7 & 16.7 & 0.8 & 0.87 \\
\hline
\end{tabular}

${ }^{a b}$ Treatments differ $(P<0.05)$.

${ }^{\text {cd }}$ Treatments differ $(P<0.10)$.

control and lasalocid, respectively. However, overall averaged daily gain was faster for goats fed lasalocid than those fed control $(P<0.05)$. Previous studies have reported that adding lasalocid to high forage diets improved (Thonney et al., 1981; Paterson et al., 1983; Spears and Harvey, 1984) or had no effect (Beacom et al., 1988; Steen et al., 1992) on growth rate in cattle or sheep. Our results using dairy goats were consistent with these observations.

Feed intake for individual goats was not measured in the growth study. It is uncertain whether the improvement in gain observed resulted from an increased efficiency, increased hay intake, or a combination of these two factors. Some reports indicated that feeding lasalocid had no effect on feed intake of animals fed high forage diets (Thonney et al., 1981; Steen et al., 1992).

Jugular blood $\mathrm{pO}_{2}$ was lower when goats were supplemented with lasalocid $(P<0.05)$. In contrast, goats fed lasalocid tended $(P<0.10)$ to have a higher $\mathrm{pCO}_{2}$ than control goats. Percent $\mathrm{O}_{2}$ saturation tended to increase $(P<0.10)$, and concentrations of total $\mathrm{CO}_{2}$ decreased slightly $(P<0.10)$ in goats fed lasalocid. Changes in blood gases could be indicative of altered metabolic activity. A lower $\mathrm{pO}_{2}$ in blood of lasalocid-fed goats might be related to a reduced respiratory rate. On the other hand, a tendency of lower total $\mathrm{CO}_{2}$ concentration in goats fed lasalocid could imply reduced metabolic acidosis (Brown et al., 2000). Percent $\mathrm{O}_{2}$ saturation in lasalocid-fed goats is close to the usual $64 \%$ saturated in venous blood of mammals (Smith et al., 1983). How changes in blood gasses reflected animal responses to lasalocid feeding was uncertain. Because lasalocid may affect acid/base balance and cellular activity by modulating ion translocation across cellular membranes (Bergen and Bates, 1984), perhaps both the atmospheric 
Table 3. Feed intake, apparent total tract nutrient digestion, and $\mathrm{N}$ utilization in castrated male dairy goats fed a high forage-low protein diet without (Control) or with lasalocid (30 mg/head/d) supplementation.

\begin{tabular}{lcccc}
\hline Item & Control & Lasalocid & SEM & $P$ \\
\hline DMI, kg/d & & & & \\
Hay & 0.73 & 0.63 & 0.03 & 0.38 \\
Total ${ }^{1}$ & 1.01 & 0.90 & 0.03 & 0.41 \\
Total tract digestion, \% & & & 1.3 & 0.56 \\
DM & 60.4 & 57.0 & 1.3 & 0.39 \\
Organic matter & 64.7 & 61.0 & 1.2 & 0.21 \\
CP & 69.1 & 72.7 & 1.6 & 0.76 \\
NDF & 61.3 & 56.9 & 1.8 & 0.25 \\
ADF & 56.4 & 52.8 & 1.1 & 0.81 \\
Cellulose & 63.3 & 62.4 & 1.8 & 0.24 \\
Hemicellulose & 70.8 & 69.4 & 0.4 & 0.55 \\
N Inputs and outputs, g/d & & & 0.67 & 0.37 \\
Intake N & 13.8 & 12.4 & 0.22 & 0.03 \\
Digested N & 9.54 & 9.13 & 0.65 & 0.68 \\
Fecal N & 4.27 & 0.43 & & 0.04 \\
Urinary N & $0.33^{\mathrm{a}}$ & 8.91 & 0.41 & 0.61 \\
Retained N & 9.22 & & 3.2 & 0.04 \\
N Partition, \% & & & 0.3 & \\
Urinary N/digested N & $3.46^{\mathrm{a}}$ & 66.3 & & \\
Retained N/intake N & $96.2^{\mathrm{b}}$ & $98.4^{\mathrm{a}}$ & & \\
Retained N/digested N & & & & \\
\hline
\end{tabular}

${ }^{1}$ Included $0.264 \mathrm{~kg} \mathrm{DM} / \mathrm{d}$ concentrate consumption for both treatments.

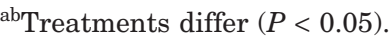

and tissue respiration might have been altered by lasalocid.

Serum glucose and urea $\mathrm{N}$ for goats fed the control diet did not differ from those of goats fed lasalocid (Table 2). Thonney et al. (1981) and Spears and Harvey (1984) observed that lasalocid increased plasma glucose in cattle. However, Spears and Harvey (1984) detected no changes in blood urea $\mathrm{N}$ with lasalocid supplementation to cattle.

\section{Metabolism Study}

Effect of feeding lasalocid on apparent total tract digestion and $\mathrm{N}$ utilization conducted using castrated male dairy goats is shown in Table 3 . Feed intake was not influenced by adding lasalocid to the diet. Similar results from metabolism studies by others were observed (Ricke et al., 1984; Wessels et al., 1996).

No significant differences were detected in digestion coefficients for all nutrient components between treatments (Table 3). Other reports also indicated no effect of lasalocid on apparent total tract digestion of feed DM, NDF, and ADF (Paterson et al., 1983; Ricke et al., 1984; Wessels et al., 1996). The numeric improvement in $\mathrm{N}$ digestibility of $5 \%$ by lasalocid is similar to the $4.6 \%$ increase in digestibility observed by Ricke et al. (1984).

Intake, digested, and fecal $\mathrm{N}$ by goats were similar between treatments (Table 3). Daily urinary $\mathrm{N}$ output was reduced $(P<0.05)$ by lasalocid supplementation. However, the amount of $\mathrm{N}$ retained did not differ significantly between treatments. When expressed as a proportion of digested $\mathrm{N}$, urinary $\mathrm{N}$ tended to reduce $(P<0.10)$, and retained $\mathrm{N}$ tended to increase $(P<0.10)$ for goats fed lasalocid. Proportions of intake N retained by goats were not different. Similar to our observations, Ricke et al. (1984) and Funk et al. (1986) did not detect any significant effect of lasalocid on $\mathrm{N}$ retention in sheep. Ricke et al. (1984) found that lasalocid decreased fecal $\mathrm{N}$ and increased absorbed $\mathrm{N}$, with no changes in urinary $\mathrm{N}$ by lasalocid. Percentage of absorbed $\mathrm{N}$, which retained was increased by lasalocid, indicated that $\mathrm{N}$ absorbed was more efficiently utilized. A high proportion of digested $\mathrm{N}$ retained was probably due to low $\mathrm{CP}$ intakes and high $\mathrm{N}$ demand.

In conclusion, supplementation of lasalocid to growing dairy goats fed a high forage, low protein diet improved average daily gain, altered blood gas parameters, increased proportion of absorbed $\mathrm{N}$ retained, and decreased urinary N. It appeared that the increased weight gain in lasalocid fed dairy goats could be attributed in part to the improved utilization of absorbed $\mathrm{N}$. How changes in blood gas parameters reflected animal responses to lasalocid feeding deserves further investigation.

\section{ACKNOWLEDGMENTS}

This research project (NSC89-2313-E-197-004) was funded by National Science Council, Taiwan, ROC.

\section{REFERENCES}

Association of Official Analytical Chemists. 1984. Official Methods of Analysis. 14th ed. Assoc. Offic. Anal. Chem., Washington, DC. 
Beacom, S. E., Z. Mir, G. O. Korsrud, W. D. G. Yates, and J. D. MacNeil. 1988. Effect of the feed additives chlortetracycline, monensin, and lasalocid on feedlot performance of finishing cattle, liver lesions, and tissue levels of chlortetracycline. Can. J. Anim. Sci. 68:1131-1141.

Beede, D. K., G. T. Schelling, G. E. Mitchell, Jr., R. E. Tucker, W. W. Gill, S. E. Koenig, and T. O. Lindsey. 1986. Nitrogen utilization and digestibility by growing steers and goats of diets that contain monensin and low crude protein. J. Anim. Sci. 62:857-863.

Bergen, W. G., and D. B. Bates. 1984. Ionophores: Their effect on production efficiency and mode of action. J. Anim. Sci. 58:1465-1483.

Brown, M. S., C. R. Krehbiel, M. L. Galyean, M. D. Remmenga, J. P. Peters, B. Hibbard, J. Robinson, and W. M. Moseley. 2000. Evaluation of models of acute and subacute acidosis on dry matter intake, ruminal fermentation, blood chemistry, and endocrine profiles of beef steers. J. Anim. Sci. 78:3155-3168.

Funk, M. A., M. L. Galyean, and T. T. Ross. 1986. Potassium and lasalocid effects on performance and digestion in lambs. J. Anim. Sci. 63:685-691.

Nocek, J. E., and J. B. Russell. 1988. Protein and energy as an integrated system. Relationship of ruminal protein and carbohydrate availability to microbial synthesis and milk production. J. Dairy Sci. 71:2070-2107.

NRC. 1981. Nutrient Requirements of Goats: Angora, Dairy, and Meat Goats in Temperate and Tropical Countries. National Academy Press, Washington, DC.

Paterson, J. A., B. M. Anderson, D. K. Bowman, R. L. Morrison, and J. E. Williams. 1983. Effect of protein source and lasalocid on nitrogen digestibility and growth by ruminants. J. Anim. Sci. 57:1537-1544.

Ricke, S. C., L. L. Berger, P. J. Van Der Aar, and G. C. Fahey, Jr. 1984. Effects of lasalocid and monensin on nutrient digestion, metabolism, and rumen characteristics of sheep. J. Anim. Sci. 58:194-202.

Russell, J. B., and S. A. Martin. 1984. Effects of various methane inhibitors on the fermentation of amino acids by mixed rumen microorganisms in vitro. J. Anim. Sci. 59:1329-1338.
Russell, J. B., and H. J. Strobel. 1989. Minireview: Effect of ionophores on ruminal fermentation. Appl. Environ. Microbiol. 55:1-6.

SAS User's Guide: Statistics. 1996. Version 6.12 Edition. SAS Inst., Inc. Cary, NC.

Smith, E. L., R. L. Hill, I. R. Lehman, R. J. Lefkowitz, P. Handler, and A. White. 1983. Hemoglobin and the Chemistry of Respiration. Pages 101-140 in Principles of Biochemistry: Mammalian Biochemistry. 7th ed. MacGraw-Hill Book Inc. New York, NY.

Spears, J. W., and R. W. Harvey. 1984. Performance, ruminal and serum characteristics of steer fed lasalocid on pasture. J. Anim. Sci. 58:460-464.

Steen, T. M, J. D. Quigley III, R. N. Heitmann, and J. D. Gresham. 1992. Effects of lasalocid and undegradable protein on growth and body composition of Holstein heifers. J. Dairy Sci. 75:2517-2523.

Thonney, M. L., E. K. Heide, D. J. Duhaime, R. J. Hand, and D. J. Perosio. 1981. Growth, feed efficiency and metabolite concentrations of cattle fed high forage diets with lasalocid or monensin supplements. J. Anim. Sci. 52:427-433.

Van Nevel, C. J., and D. I. Demeyer. 1988. Manipulation of rumen fermentation. Pages 387-443 in The Rumen Microbial Ecosystem. ed. P. N. Hobson. Elsevier Science Publishers LTD, Essex, England.

Van Soest, P. J. 1982. Rumen microbes. Pages 152-177 in Nutritional Ecology of the Ruminant. O \& B Books, Inc., OR.

Van Soest, P. J., J. B. Robertson, and B. A. Lewis. 1991. Methods for dietary fiber, neutral detergent fiber, and nonstarch polysaccharides in relation to animal nutrition. J. Dairy Sci. 74:35833597.

Wessels, R. H., E. C. Titgemeyer, C. K. Armendariz, and G. St. Jean. 1996. Lasalocid effects on ruminal degradation of protein and postruminal supply of amino acids in Holstein steers. J. Dairy Sci. 79:1802-1808.

Wiltrout, D. E., and L. D. Satter. 1972. Contribution of propionate to glucose synthesis in lactating and nonlactating cows. J. Dairy Sci. 55:307-317.

Yang, C.-M. J., and J. B. Russell. 1993. The effect of monensin supplementation on ruminal ammonia accumulation in vivo and the numbers of amino acid-fermenting bacteria. J. Anim Sci. 71:3470-3476. 